\title{
Transformation Kinetics and Mechanical Properties of Copper-Alloyed and Copper-Nickel Alloyed ADI
}

\author{
Marcin Górny ${ }^{1, a^{*}}$, Edward Tyrała ${ }^{1, b}$ and Gabriela Sikora ${ }^{1, c}$ \\ ${ }^{1}$ AGH University of Science and Technology, Faculty of Foundry Engineering, Reymonta Str. 23, \\ 30-059, Kraków, Poland \\ amgorny@agh.edu.pl, btyrala@agh.edu.pl, 'gsikora@agh.edu.pl
}

Keywords: Austempered Ductile Iron; Phase transformation; Dilatometry; Mechanical properties

\begin{abstract}
In this study the effect of copper and nickel in shaping the structure and properties of ADI (Austempered Ductile Iron) was investigated. The austenitization and austempering transformations were studied in order to follow the changes exhibited in transformation kinetics. The dilatometric results indicated that the addition of $\mathrm{Cu}$ and the addition of both $\mathrm{Cu}$ and $\mathrm{Ni}$ resulted in reducing relative expansion during austenitization, due to a larger pearlite fraction in the microstructure. In the initial stage of the austempering process, the addition of $\mathrm{Cu}$, and to a greater extent, additions of both $\mathrm{Cu}$ and $\mathrm{Ni}$ led to a reduction in the transformation rate, shifting the maximum transformation rate values toward longer times. X-ray diffraction, dilatometric, metallographic and magnetic examinations allowed us to determine the phases fraction in the structure of ADI with the presence of $\mathrm{Cu}$ and Ni. From SEM-EDS analysis, it follows that in the copper alloyed ADI, highly dispersed particles are formed containing $\mathrm{Mg}$ and $\mathrm{Cu}$, whose size does not exceed $<1 \mu \mathrm{m}$. The exhibited mechanical properties were determined as a function of $\mathrm{Cu}$ and $\mathrm{Ni}$ additions and also variable austempering period of time. It was found that the addition of $\mathrm{Cu}$ resulted in increased tensile strength and hardness but simultaneously decreased the impact strength of ADI. The outcome of this work indicates that in order to obtain a satisfactory combination of static and dynamic mechanical properties of ADI, an optimal combination - aside from proper heat treatment - $\mathrm{Cu}$ and $\mathrm{Ni}$ should be selected.
\end{abstract}

\section{Introduction}

Austempered ductile iron (ADI) is produced as a result of the heat treatment of spheroidal graphite cast iron so as achieve an optimal combination of strength, ductility and toughness [1-2]. In literature there are numerous papers published on ADI, particularly on the kinetics of austenitizing and austempering processes [3-8], structural formation, mechanical and fatigue properties [9-13], machinability [14], as well as other applications [1,13].

Copper and nickel are amongst the most common alloying elements used in cast iron [15-18]. In commercial practice, $\mathrm{Cu}$ (up to $1.5 \mathrm{wt} . \%$ ) and $\mathrm{Ni}$ (up to $2.0 \mathrm{wt} . \%$ ) are used for the production of high strength ADI's with high hardenability and ductility. $\mathrm{Cu}$ and $\mathrm{Ni}$ promote the formation of pearlite by retarding carbon diffusion in austenite. $\mathrm{Cu}$ and $\mathrm{Ni}$ increase tensile strength, yield strength and hardness while on the other hand they decrease ductility and impact resistance of ductile iron. In ADI, copper and nickel increase the maximum wall thickness that can be successfully austempered during heat treatment. They also segregate close to graphite regions and their distribution practically remains unchanged even after long heat treatment [19]. This segregation affects the microstructure and final properties of ADI. Copper and nickel according to literature have no significant effect on tensile properties, but increase ductility at austempering temperatures below $350^{\circ} \mathrm{C}$ as reported by Erić at al [20]. The present study investigates the effect of $\mathrm{Cu}$ and $\mathrm{Ni}$ additions on the austempering kinetics of ductile cast iron. In addition, mechanical properties were determined as a function of $\mathrm{Cu}$ and $\mathrm{Ni}$ additions and also variable austempering time. 


\section{Experimental}

The experimental melts were prepared in a $15 \mathrm{~kg}$ capacity crucible using an electrical induction furnace of intermediate frequency. The furnace charge consisted of Sorelmetal (High Purity Pig Iron: $4.46 \% \mathrm{C}, 0.132 \% \mathrm{Si}, 0.01 \% \mathrm{Mn}, 0.006 \% \mathrm{~S}, 0.02 \% \mathrm{P}$ ), technically pure silicon, Fe-Mn, steel scrap, copper and nickel. After melting at $1490^{\circ} \mathrm{C}$, the liquid metal was held for 2 minutes followed by spheroidization and inoculation operations using the bell method. $1.5 \mathrm{wt} . \%$ of a spheroidizer (44$48 \% \mathrm{Si}, 5-6 \% \mathrm{Mg}, 0.8-1.2 \% \mathrm{RE}, 0.8-1.2 \% \mathrm{Ca}$, Fe: balance) was used for spheroidization, while 0.5 wt. $\%$ of inoculant (73-78\% Si, $0.75-1.25 \% \mathrm{Ca}, 0.75-1.25 \% \mathrm{Ba}, 0.75-1.25 \% \mathrm{Al}$, Fe: balance) was used for inoculation purposes. The cast iron was poured at $1400^{\circ} \mathrm{C}$ into $\mathrm{Y}$ block $(13 \mathrm{~mm})$ ingots following the ASTM A 536-84 standard. Four melts were prepared with $\mathrm{Cu}, \mathrm{Ni}$, with both $\mathrm{Cu}+\mathrm{Ni}$ additions and without alloying additives. Chemical composition of the experimental ductile irons was evaluated using a SPECTRAMAXx emission spectrometer as shown in Table 1.

Table 1. Chemical composition of the investigated ductile irons

\begin{tabular}{|c|c|c|c|c|c|c|c|c|}
\hline \multicolumn{8}{|c|}{ Chemical composition } \\
\hline Alloy & $\mathrm{C} \%$ & $\mathrm{Si} \%$ & $\mathrm{Mn} \%$ & $\mathrm{P} \%$ & $\mathrm{~S} \%$ & $\mathrm{Mg} \%$ & $\mathrm{Cu} \%$ & $\mathrm{Ni} \%$ \\
\hline A & 3.60 & 2.66 & 0.38 & 0.03 & 0.01 & 0.042 & 0.01 & 0.02 \\
\hline B & 3.63 & 2.63 & 0.35 & 0.03 & 0.01 & 0.041 & 1.02 & 0.01 \\
\hline C & 3.65 & 2.73 & 0.42 & 0.03 & 0.01 & 0.039 & 0.01 & 1.05 \\
\hline D & 3.55 & 2.57 & 0.42 & 0.03 & 0.01 & 0.044 & 1.05 & 1.12 \\
\hline
\end{tabular}

The heat treatments consisted of: (a) Austenitizing in a silite furnace at $900{ }^{\circ} \mathrm{C} \pm 2{ }^{\circ} \mathrm{C}$ for 40 minutes, (b) austempering in a salt bath of $\mathrm{NaNO}_{2}-\mathrm{KNO}_{3}$ at $380^{\circ} \mathrm{C} \pm 2{ }^{\circ} \mathrm{C}$ for up to 2 hours and (c) air cooling to room temperature.

The dilatometric studies were performed using a DI-105 absolute dilatometer. In this case samples were austenitized at $900^{\circ} \mathrm{C} \pm 1^{\circ} \mathrm{C}$ for 40 minutes, (b) austempering in a salt bath of $\mathrm{NaNO}_{2-}$ $\mathrm{KNO}_{3}$ at $380^{\circ} \mathrm{C} \pm 1^{\circ} \mathrm{C}$ for 2 hours. An average cooling rate from austenitizing to an isothernal austempering was $20^{\circ} \mathrm{C} / \mathrm{s}$. In addition, a JEOL JSM-5500LV scanning electron microscope (SEM) was employed for metallographic characterization and for observations of graphite morphology.

The volume fraction of austenite was determined by means of (i) dilatometric studies $\left(\mathrm{f}_{\gamma \mathrm{d}}\right)$, (ii) metallographic examinations $\left(f_{\gamma \mathrm{m}}\right)$, (iii) Variable magnetic field $\left(\mathrm{f}_{\gamma \mathrm{mf}}\right)$ and (iv) X-ray diffraction $\left(\mathrm{f}_{\gamma \mathrm{x}}\right)$. A metallographic determination of the volume fraction of austenite was made using a Leica QWin v3.5 quantitative analyzer. X-ray diffraction was carried out with a D500 Kristalloflex (Siemens) with $\mathrm{Cu} \mathrm{K} \mathrm{K}_{\alpha}$ radiation at $40 \mathrm{kV}$ and $40 \mathrm{~mA}$ and with a step scan at $0.02^{\circ}$ in the $2 \theta$ range of 25 to $125^{\circ}$. Regarding a variable magnetic field, it is assumed that in the reversible range of the magnetic field, the magnetic dispersion of the alloy $\left(\mathrm{k}_{\mathrm{s}}\right)$ can be determined by the eq. (1) [21]:

$$
\mathrm{k}_{\mathrm{s}}=\sum \mathrm{k}_{\alpha \mathrm{i}} * \mathrm{~V}_{\alpha \mathrm{i}}
$$

where: $\mathrm{k}_{\mathrm{s}}-$ magnetic dispersion of the alloy, $\mathrm{k}_{\mathrm{\alpha i}}-$ magnetic dispersion of the $\mathrm{i}$-th phase component; $\mathrm{V}_{\mathrm{ai}}$ - volumetric fraction of the $\mathrm{i}$-th phase.

For ADI cast iron with a specific magnetic dispersion value $\mathrm{k}_{\mathrm{s}}$, the volume fraction of austenite $\mathrm{V}_{\gamma}$ can be expressed as:

$$
\mathrm{V}_{\gamma}=\left(\mathrm{k}_{\mathrm{s}}-\mathrm{k}_{\mathrm{F}-\mathrm{G}}\right) /\left(\mathrm{k}_{\mathrm{A}}-\mathrm{k}_{\mathrm{F}-\mathrm{G}}\right) * 100[\%]
$$

where: $\mathrm{k}_{\mathrm{F}-\mathrm{G}}=0.120$ - magnetic dispersion specified for spheroidal graphite cast iron with a ferritic matrix (after ferrite annealing), $\mathrm{k}_{\mathrm{A}}=0.775$ - austenite magnetic dispersion [21].

Strength testing was carried out on flat samples (in accordance with the ASTM E8M Standard) by means of a Zwick/Roell Z050 device equipped with a macro extensometer. The strain rate was set to $0.008 \mathrm{~s}^{-1}$. An unnotched Charpy test was performed on specimens in the size of $55 \times 10 \times 10 \mathrm{~mm}$, as per the ASTM specification A327-80, which were machined from the bottom part of these Y-shaped castings. 


\section{Results and Discussion}

\subsection{Kinetics of the austempering transformation}

The kinetic of the austempering transformation was followed by dilatometric means. The method is based on determination of the relative expansion of the material under investigation as a function of time and temperature. The JMA (Johnson-Mehl-Avrami) equation given below was used for describing the isothermal transformation processes:

$$
f=\exp (-1 / n t)
$$

where $f$ is the volume fraction of the transformation product and $n$ is a curve-shape constant valid for a given transformation condition. Figure 1 shows the first derivatives of the dilatometric curves with respect to time indicating transformation rates. From dilatometric results, quantitative parameters describing the austempering transformation kinetics were determined and they are given in Table 2.

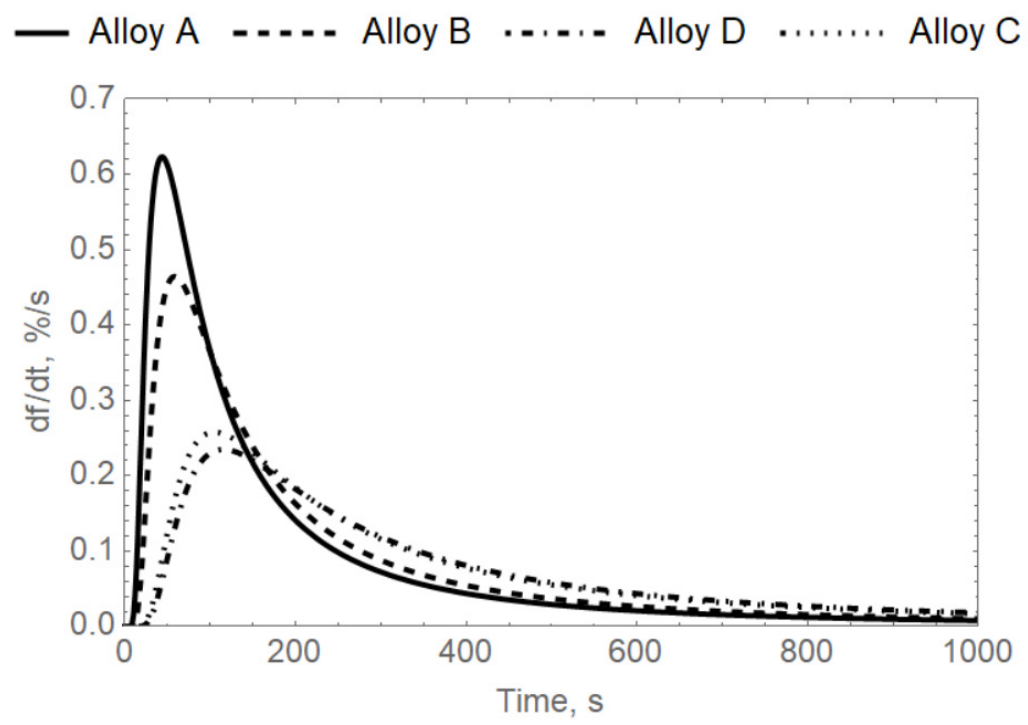

Fig. 1. Transformation rates

Table 2. Kinetic parameters for ausferritic transformation

\begin{tabular}{|c|c|c|c|c|c|c|}
\hline Alloy & $\begin{array}{c}\text { I stage, } \mathrm{t}_{\mathrm{I}}, \\
\mathrm{s}\end{array}$ & $\begin{array}{c}\text { II stage, } \mathrm{t}_{\mathrm{II}}, \\
\mathrm{s}\end{array}$ & $\begin{array}{c}\text { III stage, } \mathrm{t}_{\mathrm{III}}, \\
\mathrm{s}\end{array}$ & $\begin{array}{c}\text { Austempering } \\
\text { transformation } \\
\text { time, } \mathrm{t}_{\mathrm{A}}, \mathrm{s}\end{array}$ & $\begin{array}{c}\text { Parameter } \mathrm{n}, \\
\times 10^{3} \\
(\mathrm{eq} .3)\end{array}$ & $\begin{array}{c}\text { Max. transition } \\
\text { rate, } \mathrm{df} / \mathrm{dt}, \\
\% / \mathrm{s}\end{array}$ \\
\hline $\mathrm{A}$ & 74 & 45 & 3094 & 3213 & 11.51 & 0.62 \\
\hline $\mathrm{B}$ & 77 & 59 & 3623 & 3759 & 8.58 & 0.46 \\
\hline $\mathrm{C}$ & 102 & 104 & 4994 & 5200 & 4.76 & 0.26 \\
\hline $\mathrm{D}$ & 133 & 115 & 6282 & 6530 & 4.33 & 0.23 \\
\hline
\end{tabular}

I stage - incubation time, $\mathrm{s}$

II stage - the time from the end of the incubation period to the maximum transformation rate, $s$ III stage - the period from reaching the maximum transformation rate to the end of the austempering transformation $\mathrm{t}_{\mathrm{III}}=\mathrm{t}_{\mathrm{A}}-\mathrm{t}_{\mathrm{I}}-\mathrm{t}_{\mathrm{II}}, \mathrm{s}$

From dilatometric studies it is found that $\mathrm{Cu}$ additions alone (alloy $\mathrm{B}$ ) do not have a significant effect on the incubation time (I stage) in contrast to nickel (alloy $\mathrm{C}$ ) and the combination of $\mathrm{Cu}$ and $\mathrm{Ni}$ (alloy D). In the case of Ni-alloyed ADI, the incubation time of the austempering transformation increases by approximately $38 \%$ whereas when both elements are involved, ie. $\mathrm{Cu}$ and $\mathrm{Ni}$, the exhibited incubation time for the austempering transformation increase by nearly $80 \%$. Just after the incubation time, there are a few thin ferrite plates [15] located inside the metastable austenite, which partly transforms into martensite. As reported in [15], the presence of these thin ferrite plates 
can be attributed to a diffusionless nucleation mechanism at the onset of the austempering transformation.

In the second stage of the austempering transformation (up to its maximum value of $\mathrm{df} / \mathrm{dt}$ ), the addition of copper, and even to a greater extent, nickel and both copper and nickel reduces its rate and moves the maximum value to the right (Fig. 1). This effect can be explained by the predominant role of $\mathrm{Ni}$ on restraining the diffusional growth of ferrite plates by hindering carbon diffusion into the surrounding austenite matrix. The maximum reached on the transformation rate curves (Fig. 1) can be considered as the moment of the maximum rate of ferrite plates nucleation. Beyond this point the growth of ferrite plates become controlled by diffusion of carbon into the austenite phase [15].

Figure 1 shows that in the third stage of austempering, the transformation rates for alloy $\mathrm{A}$ and copper alloyed (alloy B) are similar (Table 2). In the case of ADI with the addition of nickel and nickel and copper, their transformation rates in the third stage are very similar to each other. For Alloy D, the longest austempering time (Table 2) had been reached, which is most affected by the slowest transformation rate at the beginning of the third stage.

Apparently, $\mathrm{Ni}$ in combination with $\mathrm{Cu}$ have the strongest effect on reducing the transformation rates through their effect on the formation of new ferrite plates.

\subsection{Volume fraction of austenite}

Besides the effect on the ausferrite morphology, $\mathrm{Ni}$ and $\mathrm{Cu}$ additions also affect the volume fraction of the phases present after the completion of the austempering process.

In table 3, austenite fractions determined by various techniques for full austempering time are presented.

Table 3. Austenite fraction

\begin{tabular}{|l|l|l|l|l|}
\hline \multirow{2}{*}{ Austenite fraction, $\%$} & \multicolumn{4}{l}{ Alloy No. } \\
\cline { 2 - 5 } & A & B & C & D \\
\hline $\mathrm{f}_{\gamma \mathrm{m}}$ & 35.0 & 37.2 & 43.3 & 45.1 \\
\hline $\mathrm{f}_{\gamma \mathrm{x}}$ & 22.6 & 28.14 & 34.57 & 34.35 \\
\hline $\mathrm{f}_{\gamma \mathrm{mf}}$ & 25.0 & 27.6 & 28.3 & 30.80 \\
\hline $\mathrm{f}_{\gamma \mathrm{d}}$ & 25.9 & 37.5 & 36.5 & 43.3 \\
\hline
\end{tabular}

Table 3 shows that the addition of nickel and copper increases the austenite fraction in ADI. It is worth noting that the results obtained by different techniques differ slightly from each other. The austenite fraction determined by metallography strongly depends on the magnification used in the study and the analysed surface area. The use of scanning electron microscopy and magnification of 4000x often produces results different from light microscopy and magnification of the order of 5001000x. XRD studies are most often used to determine the residual austenite fraction in ADI cast iron. The analysis of the results obtained with this technique shows that, depending on the type of XRD device and the standard used, the results may vary from each other. Dilatometric methods can also be employed to estimate the residual austenite fraction in addition to the information about the transformation kinetics. It is also possible to assess the volumetric fraction of paramagnetic components through the magnetic method [21]. Such tests allow the ferromagnetic component to be determined in a short time and the accuracy of its determination depends on the selected standard. According to Table 3, the results of austenite fraction through the magnetic method are similar to those obtained by XRD. The qualitative and quantitative assessment of phase composition is extremely important for the analysis of the influence of technological factors (eg chemical composition) on the structure and properties of ADI cast iron. The presented analysis shows that there are different methods for determining the austenite fraction, and the results obtained by different methods may vary significantly from one another, which may affect the correct interpretation of the results. 


\subsection{SEM investigation of fractures}

All specimens exhibit a mixture of ductile and cleavage fracture mode, regardless of the addition of alloying elements $(\mathrm{Cu}, \mathrm{Ni}$ and $\mathrm{Cu}+\mathrm{Ni})$. The effect of alloying ADI with $\mathrm{Cu}$ on fracture morphology is illustrated in Fig. 2. Close examination revealed the presence of ellipsoidal shaped precipitate with a size below $1 \mu \mathrm{m}$ in the ADI fracture of alloy B (Fig. 2) and D. TEM observations [22] allowed us to identify these precipitates as $\mathrm{Mg}_{2} \mathrm{Cu}$ with an orthorhombic structure. It should also be noted that these particles (which are fragile due to their crystallographic structure) are mainly located in the vicinity of graphite nodules in the region of a dimpled fracture [22].

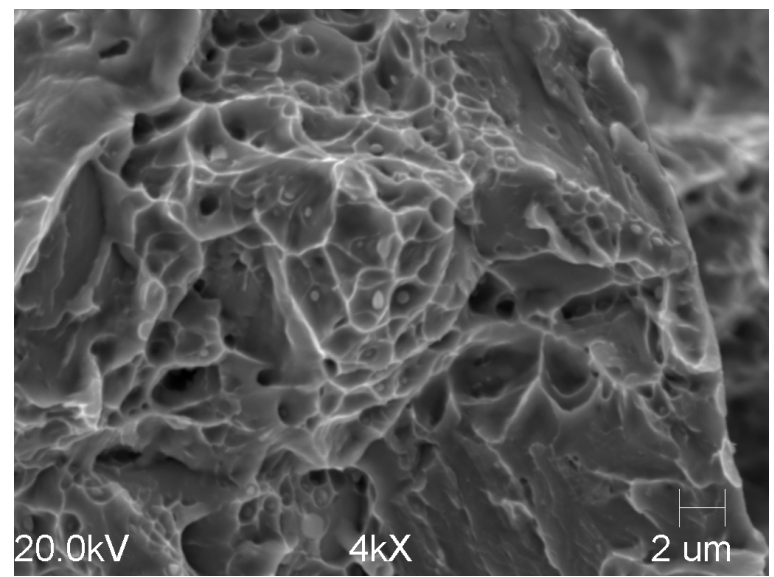

Fig. 2. Fracture morphology of ADI in alloy B (with the addition of copper) showing $\mathrm{Mg}_{2} \mathrm{Cu}$ particles

\subsection{Tensile and impact properties}

The effect of alloying ADI with $\mathrm{Cu}, \mathrm{Ni}$ and $\mathrm{Cu}+\mathrm{Ni}$ on the mechanical properties is illustrated in Fig. 3.

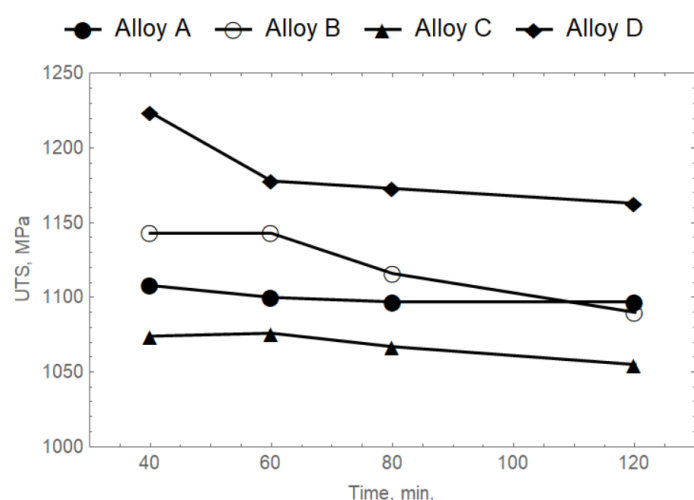

a)

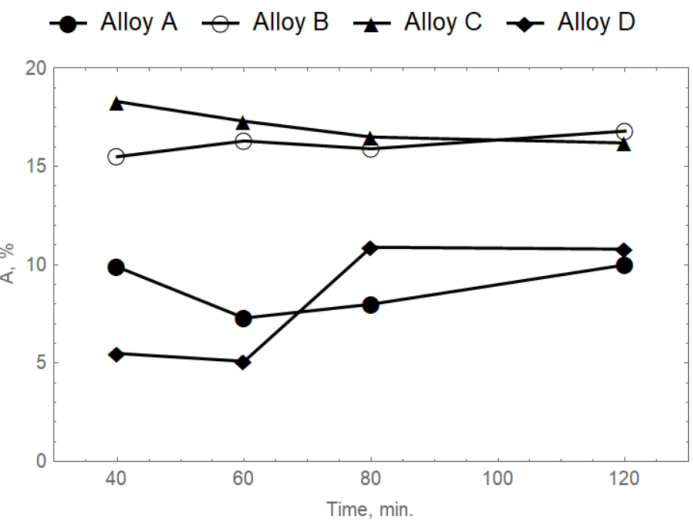

c)

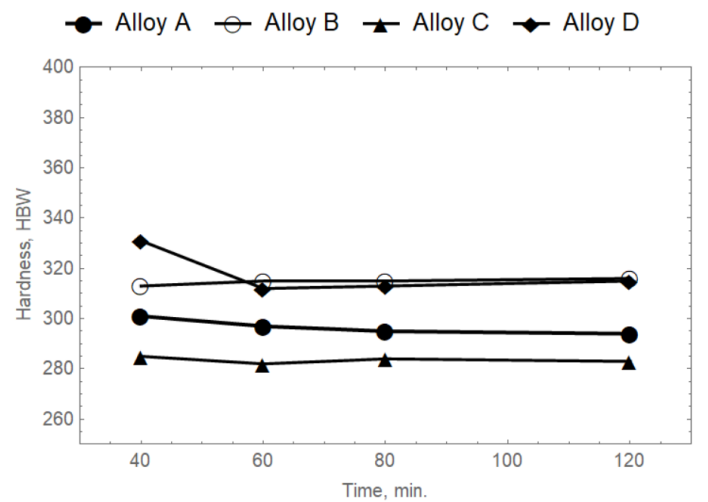

b)

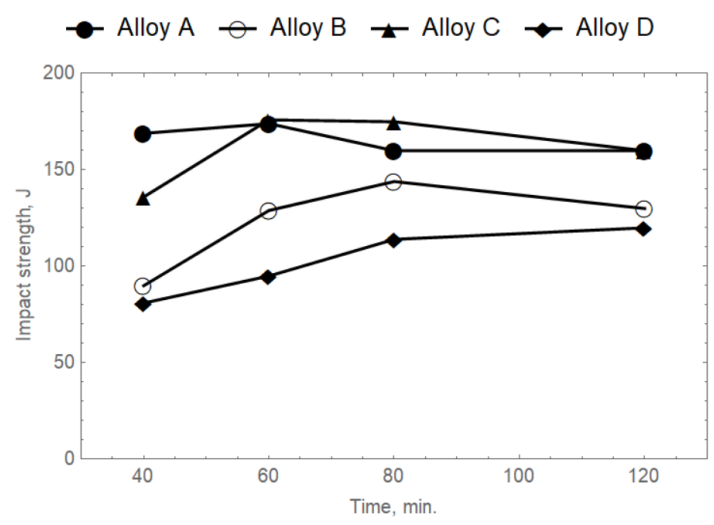

d)

Fig. 3. Mechanical properties ie: a) Tensile strength (UTS), b) Hardness, c) elongation and d) impact strength of ADI as a function of austempering time and alloying additions. Curves: bluealloy A, brown -alloy B, Black - alloy C, Red - alloy D 
Figure 3 shows that ADI cast iron with the addition of copper (alloys B) and both copper and nickel (alloy D) have the highest tensile strength and hardness. The highest UTS and hardness values were obtained during a short austempering time (40 min.). ADI with copper and copper and nickel has the lowest impact strength (Fig. 3d). It is worth noting that $\mathrm{Cu}$-alloyed ADI (alloy B) has very good plasticity at $15 \%$, similar to Ni-alloyed ADI (alloy C). ADI without the addition of copper (alloys $\mathrm{A}$ and $\mathrm{C}$ ) has the highest impact strength. In these copper-free $\mathrm{A}$ and $\mathrm{C}$ alloys, in the full austempering time range ie. from 40 up to 120 minutes, impact strength is at the level of 136$180 \mathrm{~J}$. In the case of copper alloyed ADI impact strength significantly decreases. In the case of alloy $\mathrm{B}$ in the entire considered time range, impact strength ranges from 90-144 J, whereas in alloy D, impact energy ranges from 81-120 J. The change in mechanical properties is related to graphite in the form of spheres (their fraction, shape and number), austenite fraction, the form of ferrite platelets, the presence of identified $\mathrm{Mg}_{2} \mathrm{Cu}$ particles, as well as the processes of metal matrix strengthening and segregation of alloying elements. Literature data suggests that the addition of copper and nickel has little effect on the mechanical properties of ADI. In the case of copper and copper and nickel alloyed ductile iron (in "as cast" conditions) significantly lowers impact strength and ductility, while an increase of hardness, tensile strength and yield strength is primarily associated with a pearlitic metallic matrix. By contrast, ADI with additions of copper, according to several studies, shows that no significant changes of tensile properties compared to iron without alloying elements were observed [15-18]. Highly-dispersive and brittle $\mathrm{Mg}-\mathrm{Cu}$ particles, have a negative effect on the impact properties of ADI. In conclusion, it can be stated that ADI with copper is characterized by good static mechanical properties but at the same time reduced dynamic properties.

\section{Conclusions}

The following conclusions can be drawn from the present experimental investigation:

1. Dilatometric studies indicate that the addition of copper (alloy B) does not have a significant effect on the incubation time for the austempering transformation. The austempering process is characterized by different transformation rates. In the initial stage, the addition of $\mathrm{Cu}$ and to a greater extent nickel and both copper and nickel additions have a marked effect on reducing the transformation rates.

2. The exhibited mechanical properties of ADI depend on $\mathrm{Cu}$ and $\mathrm{Ni}$ additions and variable austempering periods of time. The addition of $\mathrm{Cu}$ resulted in an increase in tensile strength and hardness but simultaneously decreased the dynamic properties of ADI. ADI with copper (alloy B) has very good plasticity of $15 \%$, similar to ADI with nickel (alloy C). Highlydispersive $\mathrm{Mg}_{2} \mathrm{Cu}$ particles present in copper alloyed ADI (alloy B and alloy D) the size of which do not exceed $1 \mu \mathrm{m}$, have a negative effect on the dynamic properties of ADI.

\section{References}

[1] B.N. Olson, K.B. Moore, and G.R. Simula, Potential for Practical Applications of Ausforming Austempered Ductile Iron, AFS Trans., 111, (2002) 965-982.

[2] M.M. Cisneros-Guerrer, R.E. Campos-Cambranis, M. Castro-Román, and M.J. Pérez-López, Austempering Kinetics in Cu-Mo Alloyed Ductile Iron: A Dilatometric Study, Adv. Mater. Res., 45 (1997) 415-420.

[3] M.M. Cisneros, M.J. Pérez, R.E. Campos, and E. Valdés, The role of $\mathrm{Cu}$, Mo and Ni on the kinetics of the bainitic reaction during the austempering of ductile irons, Int. J. Cast Met. Res. 11 (1999) 425-430.

[4] D.J. Moore, J.R. Parolini, and K.B. Rundman, Effect of manganese on structure and properties of austempered ductile iron: a processing window concept, AFS Trans., 111 (2002) 911-930. 
[5] D. Venugopalan, A kinetic model of the $\gamma \rightarrow \alpha+\mathrm{Gr}$ eutectoid transformation in spheroidal graphite cast irons, Metall. Trans. A, 21 (1990) 913-918.

[6] K.F. Laneri, J. Desimoni, R.C. Mercader, R.W. Gregorutti, and J.L. Sarutti, Thermal Dependence of Austempering TransformationKinetics of Compacted Graphite Cast Iron, Metall. Mater. Trans. A, 32 (2001) 51-58.

[7] S.M. Butorabi and A.A. Fallah, Austempering kinetics of low carbon-aluminium cast iron, AFS Trans., 105 (1997) 757-761.

[8] K.L. Hayrynen and K.R. Brandenberg: Carbidic Austempered Ductile Iron ( CADI)- the New Wear Material, AFS Trans., 111 (2003) 845-850.

[9] J. Mallia and M. Grech, Efect of silicon content on impact properties of austempered ductile iron, Mater. Sci. Technol., 13 (1997) 408-414.

[10]N. Darwish and R. Elliott, Austempering of low manganese ductile irons: part 1 processing window, Mater. Sci. Technol., 9 (1993) 882-889.

[11] S. Biswas, Ch. Monroe, and T. Prucha, Use of Published Experimental Results to Validate Approaches to Gray and Ductile Iron Mechanical Properties Prediction, Int. J. Met. (2017) 1-19.

[12]F. Zanardi, Fatigue properties and machinability of ADI, Metall. Ital. 10 (2005) 27-32.

[13]J.R. Keough, K.L. Hayrynen, and G.L. Pioszak, Designing with Austempered Ductile Iron (ADI), AFS Procedings 10 (2010) 1-15.

[14]F. Zanardi, Machinable ADI in Italy, AFS Trans. 113 (2005) 835-847.

[15]M. Górny, E. Tyrała, and H.F. Lopez, Effect of Copper and Nickel on the Transformation Kinetics of Austempered Ductile Iron, J. Mater. Eng. Perform. 23 (2014) 3505-3510.

[16] U. Batra, S. Ray, and S.R. Prabhakar, The influence of nickel and copper on the austempering of ductile iron, J. Mater. Eng. Perform. 13 (2004) 64-68.

[17] K. Osamura, H. Okuda, S. Ochiai, M. Takashima, K. Asano, M. Furusaka, K. Kishida, and F. Kurosawa, Precipitation Hardening in $\mathrm{Fe}-\mathrm{Cu}$ Binary and Quaternary Alloys, ISIJ Int. 34 (1994) 359-65.

[18] M. Tsujikawa, N. Matsumoto, K. Nakamoto, and Y. Michiura, Pearlite Stabilisation by Copper on Ductile Cast Iron, Key Eng. Mater. 457 (2010) 151-156.

[19] M. Nili-Ahmadabadi and M. Mosallaiee-Pour, Homogenization of ductile iron using partialmelting aided by modeling, Mater. Sci. Eng. A 373 (2004) 309-14.

[20] O. Erić, D. Rajnović, S. Zec, L. Sidjanin, and M.T. Jovanović, Microstructure and fracture of alloyed austempered ductile iron, Mater. Charact. 57 (2006) 211-17.

[21]E. Tyrała, Phase Composition Using a Variable Magnetic Field, ISIJ Int. 54 (2014) 700-703.

[22] M. Górny, E. Tyrała, G. Sikora, and Ł. Rogal, Identification of Mg2Cu Particles in Cu Alloyed Austempered Ductile Iron, Met. Mater. Int. 24 (2018) (in print). 